The intraday price behavior of Australian exchange traded options and warrants

William J. Bertin

School of Business

Bond University

Gold Coast, Qld 4229, Australia

Tel: +61 755952210

Email: wbertin@bond.edu.au

David Michayluk

School of Finance and Economics

University of Technology, Sydney

Australia

Phone: 61-2-9514-7761

Fax: 61-2-9514-7711

E-mail: david.michayluk@uts.edu.au

Laurie Prather*

School of Business

Bond University

Gold Coast, Qld 4229, Australia

Tel: +61 755952073

Email: 1prather@bond.edu.au

* Corresponding author

EFM Classification codes 310, 360, 440 


\title{
The intraday price behavior of Australian exchange traded options and warrants
}

\begin{abstract}
This study focuses on the price discovery process in Australian option and warrant markets. Characterizing these two markets in terms of their cost structures and institutional features, we formally test competing price discovery hypotheses. The general findings indicate that the warrants market is the dominant market suggesting that their lower trading cost outweigh their less attractive institutional features. Additionally, we find that idiosyncratic differences among firms may result in a clientele effect thus providing justification for the coexistence of these seemingly redundant markets.
\end{abstract}

Keywords: Options and warrants, price discovery, error correction models.

JEL Classification: G14, G15 


\section{The intraday price behavior of Australian exchange traded options and warrants}

\section{Introduction}

In 1991 the Australian Stock Exchange (ASX) introduced exchanged traded equity warrant contracts. In direct competition with existing exchange traded equity options, these warrant contracts offer the holder the right, but not the obligation, to buy or sell a given quantity of an asset at or before a pre-specified date for a given price. Additionally, as in the case of equity options, the exercise of warrants results in either a transfer of ownership in existing equity in exchange for the exercise price, or a cash settlement depending on contract specifications. ${ }^{1}$

While the ASX's warrant and option markets offer two securities that are technically distinct, they are inextricably linked by the existence of arbitrage opportunities that arise due to their identical payoff functions. Consistent with efficient markets and the law of one price, Hasbrouck (1995) argues that the reference to 'one security' is applicable to two technically distinct but informationally linked securities governed by arbitrage possibilities. These two markets offer derivative securities that share the same fundamental characteristics such as underlying asset, strike price, expiration date, type (call or put), and exercise style, thus providing a unique opportunity to examine pricing dynamics in the two markets and to evaluate the relative importance of various price discovery hypotheses. ${ }^{2}$

\footnotetext{
${ }^{1}$ In contrast to company issued warrants, exchange traded warrants do not result in the creation of new shares when exercised and thus there is no dilution of value for existing shareholders.

${ }^{2}$ A discussion detailing the operational features of warrant and option markets is provided in Section III.
} 
In evaluating these markets and securities, the law of one price states that in an efficient market all identical goods must trade at one price. Furthermore, under the efficient market hypothesis, prices adjust instantaneously and unbiasedly to new public information. Thus, in keeping with the law of one price, as new information enters the market, price changes of related securities should be contemporaneously correlated. In this context Kim et al. (1999) propose that with market efficiency, if one security is traded in two separate markets, informed traders will be indifferent between transactions in either market, and new information will be simultaneously incorporated into prices. In practice, however, lead/lag price change relationships between markets and/or securities result from market frictions impeding the price discovery process. Chan, Chung, and Johnson (1993) recognizing the existence of price discrepancies indicate that arbitrage trading ensures only short-lived lead/lag relationships.

The focus of this study is on the price discovery process in the Australian option and warrant markets. Specifically, we characterize both markets in terms of their respective cost structures and institutional features, and then we formally test the competing price discovery hypotheses related to trading costs and institutional environment. Findings document lower trading costs in the warrants market, although the institutional environment for trading warrants is less attractive than the environment for trading options. The empirical tests strongly support cointegrated markets thus establishing the existence of a long run equilibrium relationship between warrant and option prices. Applying an error correction model to the data, the options market response to deviations from the long run equilibrium condition is stronger than that of the warrants market. This suggests that the warrants market is the dominant market, and that trading costs are more influential than the institutional environment in terms of price discovery. 


\section{Literature}

While the efficient market theory (EMT) supports contemporaneously correlated price changes across informationally linked markets, empirical studies document the existence of lead/lag relationships. Such results contradicting EMT have lead to the development of several hypotheses regarding market imperfections on the price discovery process. One of the most widely supported hypotheses centers on trading costs. Fleming, Ostdiek, and Whaley (1996) formalize the trading cost hypothesis and argue that information based trades result in maximum net profits when they are executed in the lowest cost market where price discovery occurs more quickly.

Continuing to focus on market imperfections, Chu, Hsieh, and Tse (1999) identify market structure as a major source of market friction and suggest that institutional differences across informationally linked markets impact the speed of price discovery. They formalize this with the institutional environment hypothesis stating that the market characterized by the most favorable trading environment naturally attracts information based trades, and they also present a leverage based explanation for observed lead/lag price changes (speed of price discovery). According to the leverage hypothesis, information trades consistently take place in the market providing the greatest leverage.

Chan (1992) formulates an information hypothesis that new market-wide information will be integrated into the price of the product that captures the entire market most quickly. ${ }^{3}$ Chan, Chung, and Johnson (1993) propose the private information hypothesis, which holds that investors with private information trade in the market that maximizes

\footnotetext{
${ }^{3}$ Chan explains leading futures prices compared to stock prices by suggesting that it is easier to capture market information by trading futures contracts on a market index rather than constructing the market portfolio from individual securities in the stock market.
} 
their profits. Considering various factors including margin requirements, borrowing restrictions, transparency, leverage, liquidity and transaction costs and their influence on profitability, the private information hypothesis synthesizes the above hypotheses.

The empirical price discovery literature is comprehensive in considering different informationally linked markets and securities. While many studies compare stock/options markets, others focus on spot/futures and options/futures markets, as well as the securities traded on different domestic and international exchanges. Despite the wealth of literature, the general findings suffer from a lack of consensus. This may be due to the nature of price discovery research where validation of a particular hypothesis proves elusive in the presence of findings that frequently support a range of hypotheses.

One of the earliest empirical studies documenting a lead/lag relationship between stock and options markets is Manaster and Rendleman (1982). Using end-of-day prices they find that option prices lead stock prices. While Anthony (1988) finds the same lead/lag relationship using daily trading volume, other studies with different data samples present conflicting results. ${ }^{4}$ Questioning some of the early studies’ methodologies, Vijh (1988) advocates using intra-day data to avoid the biases introduced with daily data and, more importantly, recognizes that previous studies fail to allow for a stock market lead. Thus, permitting a stock market lead and using intra-day data, Stephan and Whaley (1990) find that the stock market leads the options market by up to fifteen minutes. Chan, Chung, and Johnson (1993) attribute this to price discreteness, while O’Connor (1999) finds that the stock market leads the options market, but the relationship depends

\footnotetext{
${ }^{4}$ Bhattacharya (1987) differentiates between overnight trading and intra-day trading and finds that the options market leads the stock market in overnight but not intra-day trading. Kumar and Shastri (1990) study non-dividend paying stocks and find no options market lead.
} 
on trading costs. Easley, O’Hara and Srinivas (1998) further document results consistent with a stock market lead.

Taking a different approach, Vijh (1990) and Srinivas (1993) test whether option trades are information related and thus have the potential to lead the underlying stock. Observing that the price effects of large option trades are generally small, Vijh concludes that option trades do not contain any information. Srinivas argues that the Vijh sample is biased and, using a different sample, finds that some information is conveyed in option trades.

While empirical studies of price discovery for the stock and options markets report mixed results, those examining spot/cash and futures markets overwhelmingly support a futures market lead. ${ }^{5}$ Considering other linked markets Fleming, Ostdiek, and Whaley (1996) find that the futures market leads the options market. Garbade and Silber (1979), Harris et al (1995) and Hasbrouck (1995) focus on the securities traded across different markets and find that prices on the New York Stock Exchange lead the regional exchanges. Additionally, from an international perspective Eun and Shim (1989), Koch and Koch (1991), Roell (1992) and Kleindon and Werner (1993) document a US market lead. Finally, the price discovery literature also extends beyond securities markets with Adrangi, Chatrath, and David (2000) identifying the price linkages between the gold and silver markets and He (1997) testing for a lead/lag relationship between various indexes including the Hang Seng, real estate, financial institutions, public utilities, and commerce and industry. Thus, the analytics of price discovery applies to markets,

\footnotetext{
${ }^{5}$ See for example, Kawaller, Koch, and Koch (1987), Cheung and Ng (1990), Chan, Chan, and Karolyi (1991), Laatsch and Schwartz (1988) Stoll and Whaley (1990), Chan (1992), Abhyankar (1995), Chu, Hsieh, and Tse (1999), Kim, Szakmary, and Schwarz (1999).
} 
securities, commodities and industries provided that they are linked to a certain degree by information flow.

A growing body of literature considers the use of trading activity to indicate the relative rate of price discovery. These studies suggest that a lead in trading activity in one market indicates that price discovery occurs most rapidly in that market. Trading volume was first posited as a proxy for the rate of information arrival by Copeland (1976), and has more recently been used by Easley, O’Hara, and Srinivas (1998) and Vijh (1990) to study the dynamics between the stock market and the options market. While traditional views of volume and its importance infer that volume is merely an outcome of the trading process, these papers (and several others) advocate the explanatory power of volume.

The remainder of the paper is organized as follows: The next section provides the hypotheses to be tested. Section II discusses the data analyzed, while Section III explores the lead/lag relationship. Section IV presents our methodology, Section V reports the results, and Section VI summarizes the paper.

\section{Hypotheses}

Based on the price discovery hypotheses contained in the literature, this paper analyzes the relationship between the Australian option and warrant markets and specifically tests the trading cost and institutional environment hypotheses. 


\section{Hypothesis 1- Trading Cost Hypothesis:}

Price discovery occurs more rapidly in the market with the lowest costs of trading. These costs of trading include the cost of immediacy, market impact costs and explicit transaction costs.

Hypothesis 2- Institutional Environment Hypothesis:

Price discovery occurs more rapidly in the market with the most attractive institutional features. These features include the trading system, the clearing procedures, the minimum tick size, the ability/inability to short sell, the default risk associated with contracts and the market maker obligations.

The leverage and market-wide information hypotheses are not considered since both the option and warrant markets' products are equally levered, and they are indistinguishable in the way they capture market-wide information. The exclusion of these two hypotheses enables a direct comparison of the trading cost and the institutional environment hypotheses.

\section{Data}

The source for both the ASX options and warrants transaction and quote data is the Securities Industry Research Center of Asia-Pacific (SIRCA). Trade information for each type of contract includes the series, ${ }^{6}$ the transaction price, the trading volume and the quote information consisting of the series and the bid-ask prices and depths. Each record contains a time stamp, accurate to the nearest second indicating either a trade or a new quote. The empirical analysis considers 65 trading days from September through November, 1999. 
To test the trading cost and institutional environment hypotheses, we match the options and warrants samples to produce pairs with identical risk/return characteristics. It is essential that both series are derivatives of the same underlying asset, have the same strike price, expiration date, and are the same type (call or put). These matching criteria result in a sample of 24 firms and 54 option/warrant series. To eliminate problems associated with non-synchronous trades, we exclude pairs with fewer than 1,000 quotes per each contract over the 3-month period. Finally, to ensure a cross-sectional perspective, the final sample includes the most liquid pair of the option/warrant series per firm. ${ }^{7}$

Table 1 provides the summary statistics for the final sample of 19 option/warrant series for 19 firms. Panels $\mathrm{A}$ and $\mathrm{B}$ of Table 1 include the overall and individual firm averages of the bid-ask spread and liquidity measures, respectively, for the options and warrants in the final sample. In the methodology (Section IV) we address further data and testing considerations.

\section{Lead/lag predictions based on the price discovery hypothesis}

\section{Trading costs}

The trading cost hypothesis proposes that price discovery occurs as a result of information trading, and as informed traders attempt to maximize returns, they will trade in the market with the lowest costs. Thus, all else equal, price discovery should occur more rapidly in the market with the lowest trading costs. This analysis considers

\footnotetext{
${ }^{6}$ Series identifies the underlying asset, expiration date, strike price and type (call or put).

${ }^{7}$ The most liquid pair is the series with the highest average number of trades for both the option series and the warrant series combined.
} 
the relative cost of trading in options markets and warrants markets, and using the trading cost hypothesis, we predict the lead/lag relationship between the two markets.

Identifying trading costs as consisting of the bid-ask spread, liquidity and explicit transactions costs, Fleming, Ostdiek and Whaley (1996) argue that the bid-ask spread is the largest component of the cost of trading. Coughenour and Shastri (1999) suggest that the bid-ask spread is the cost of immediacy imposed upon an investor, and thus also represents a frictional measure of liquidity, which is consistent with Stoll (2000).

For all option and warrant series included in the final sample, we compare the average quoted bid-ask spread, percentage quoted bid-ask spread, effective bid-ask spread and percentage effective bid-ask spread. Regardless of the spread measure, the results presented in Table 1, Panel A overwhelmingly indicate lower trading costs in the warrants market. In particular, the quoted bid-ask spread for warrants is lower than in the options market for 18 of the 19 firms, and, on average, the quoted bid-ask spread is more than two times higher in the options market. The other spread measures offer similar results. For example, the percentage quoted bid-ask spread is lower for warrants, although the magnitude of difference is smaller. This is a due to the effects of conversion ratios greater than one (any warrant series with a conversion ratio greater than 1:1 trades at a fraction of the comparable option series). As a result of trades executed within the quoted prices, the effective spread measures indicate a narrower bid-ask spread in both markets, however, warrants still exhibit lower trading costs than options. Based on these results, price discovery should occur in the warrants market. Additionally, Wilcoxon Rank Sums Test (WRST) statistic indicates that all of the option spread measures are significantly larger (1\% level) than those of the warrants. 
Liquidity is a frequently cited explanation for the speed of price discovery between markets. Adrangi, Chatrath, and David (2000) recognize that information is most likely to disseminate from more liquid markets to those with lower liquidity. We compare liquidity measures such as market depth, trading volume, and trade size to assess the relative liquidity of option and warrant markets.

Market depth reflects the ability to trade a specified quantity of contracts at the quoted bid or ask prices. Deep markets allow for large transactions at quoted prices, while shallow markets permit a relatively small number of contracts to be traded at the quote with additional contracts being traded at a less favorable price. Hence, measures of depth are effectively market impact measures, and as such, we examine the average bid and ask depths.

Trading volume and transaction size can also be used to infer market liquidity. In order for price discovery to take place, trades must be executed so that security prices reflect new information. Therefore, a lower volume market will appear to lag a higher volume market, until such time as a transaction is executed, and the price is updated with new information. Fleming, Ostdiek, and Whaley (1996) refer to this as the effect of infrequent trading. In this study we use the average daily volume of traded contracts in each market as a proxy for volume. In a similar context, transaction size also conveys liquidity information. For example, a market that handles larger trades at quoted prices is more liquid than a market that requires a price concession for those trades. Thus, average transaction size proxies for the ability to trade at quoted prices. 
We calculate each of the above liquidity measures in share equivalents. Since one option contract is based upon 1,000 shares, the share equivalent for depth, volume or size is 1,000 times the measure expressed as a number of contracts. The share equivalent for a warrant contract is determined by the conversion ratio. For example, the share equivalent for a warrant series with a conversion ratio of 2:1 is one share per two contracts.

Table 1, Panel B reports the liquidity measures calculated for all option and warrant series included in the final sample. With respect to market depth, the figures indicate that the option and warrant markets are similar. The average bid depth and ask depth in the options market is a share equivalent of 17,259.16 and 16,493.72, respectively, while the same measures in the warrants market are slightly higher at 19,118.51 and 19,197.51, respectively. The WSRT statistics also indicate no significant differences between the depth variables for the two markets.

Comparing average daily volume indicates greater activity in the warrants market, as the volume over all firms is on average more than 20,000 shares higher. While this relationship is generally consistent across firms with higher average daily volume for 16 out of the 19 sample firms in the warrants market, the WSRT indicates no significant difference in the average daily volume between the markets. Alternatively, the average transaction size in the options market is larger (more than three times) than in the warrants market, and this difference between the two markets is statistically significant. On an individual basis, this relationship holds for 15 of the 19 sample firms. While this result points to a more liquid options market, the average option transaction size is greater than bid-ask depths, thus indicating that the average option trade requires a price 
concession. In contrast, the average warrant transaction size is approximately half the bid-ask depths suggesting that warrants can be executed at quoted prices. Even though the options market generally features larger trades, those trades are conducted less frequently than in the warrants market and as noted previously may require price concessions. Furthermore, Jones, Kaul, and Lipson (1994) argue that volume moves prices and trade size has no information content per se. Within this context the transaction size advantage of the options may be limited.

Explicit transaction costs consider the observable fixed and variable costs of brokers. The ASX imposes the same fee and rebate structure for all brokers, thus providing a standardized measure. Variable costs presented in Table 2 include those associated with obtaining quotes, placing orders, executing trades, settlement and clearing, and exercising contracts. While costs associated with obtaining quotes and exercising contracts are identical in the option and warrant markets, those associated with transactions (placing an order, executing a trade, and then settlement) are different. Specifically, warrant contracts include a fee for placing orders (whether or not they are filled), a trading fee based upon the value of the trade, and a settlement fee for each order. The total of these costs are comparable to the flat registration fee associated with trading option contracts, but complicated by the different basis on which these fees are calculated. ${ }^{8}$ By netting out the common costs, the remaining option fees are equal to $1.02 \mathrm{n}$, where $\mathrm{n}$ is the number of contracts, and warrant fees are equal to $1.29+2$ (Trade Value/100,000).

\footnotetext{
${ }^{8}$ Option contract fees are calculated per contract, while warrant contract fees are calculated on trade value, per trade and per order.
} 
Based on these explicit costs, for trade sizes equal to one contract, the option trading cost will always be less than that of the warrant, regardless of the trade value. By contrast, as the number of contracts increases, the warrant contracts' transaction costs fall below the options' costs up to a given trade value. For example, if two option contracts equivalent to 2,000 shares are traded, the trade value for the warrant equivalent shares must be greater than $\$ 37,500.00$ (or a warrant price greater than \$18.75) for the options market to have lower costs. ${ }^{9}$ Given that warrant prices seldom reach this level, execution costs for warrants are typically lower than similar options transactions. Additionally, Table 1, Panel B indicates that the average transaction size in the options market exceeds 33 contracts $(33,864.74 / 1000)$, providing further evidence that the explicit variable trading costs are lower in the warrants market.

The fixed component of explicit transaction costs consider services essential to operating in a particular market, such as the cost of equipment and personnel training. As illustrated in Table 2, fixed costs are lower in the warrants market. Their small magnitude, however, suggests these costs have limited impact on overall trading cost comparisons.

Table 3 summarizes the previously discussed trading costs and provides the price relationship between the option and warrant markets as predicted by the trading cost hypothesis. Regardless of the bid-ask spread measure, trading costs are lower in the warrants market, and thus information will flow from the warrants market to the options market. Although the liquidity proxies appear to provide mixed results, as previously discussed, transaction size plays a less important role than average daily volume.

\footnotetext{
${ }^{9}$ This price of $\$ 18.75$ is based on a conversion ratio of 1:1 and will be lower for higher conversion ratios.
} 
Finally, we find lower explicit variable trading costs in the warrants market. Overall, this examination indicates lower costs associated with warrants markets, and thus, according to the trading cost hypothesis, price discovery should occur more rapidly in that market.

\section{Institutional Environment}

Differences in the institutional environment of the option and warrant markets will affect their relative attractiveness. Theory suggests that all else equal, price discovery will occur in the market with the most favorable characteristics. While both the markets operate under the umbrella of the ASX, they may be differentiated by features including trading and clearing systems, minimum tick size, shortselling restrictions, default risk and market maker obligations.

Two fundamental differences between option and warrant trading systems include broker accessibility and system functionality. Options trade via the Derivatives Trading Facility (DTF), whereas warrants trade on the Stock Exchange Automated Trading System (SEATS), which is the same system for trading ASX shares. Since all brokerage firms trade ASX shares, they automatically have access to the warrants market. Obtaining access to the options market, however, requires an additional investment in a DTF system. This additional cost suggests that the warrants market has a slight advantage in the speed of price discovery. ${ }^{10}$

Despite the additional investment, the DTF system offers greater functionality and sophistication than SEATS. For example, DTF allows brokers to enter multiple leg 
orders (a series of related buy and sell orders), thus enabling a broker to lock in a set price for an entire strategy. A similar order in SEATS faces the risk that some, but not all of the strategy components will be executed. Additionally, the DTF system simultaneously displays market information for all option series related to a given underlying asset, while SEATS only provides information for a single warrant series at a time.

Differences in clearing procedures may influence an investor's decision regarding where to trade. The Options Clearing House $(\mathrm{OCH})$ clears contracts in the options market, and warrant contracts are cleared in the same manner as the underlying stock by the Clearing House Electronic Sub-Register System (CHESS). In terms of clearing procedures, the settlement period in the warrants market is one day longer than it is in the options market. Considering the time value of money, the party with the long (short) position may prefer to delay (expedite) payment (receipt). ${ }^{11}$ Thus the price discovery impact depends on whether the market is dominated by buyers or sellers. The fact that one party to a contract will always be better off due to the asymmetric benefit is likely to be incorporated into contract prices, and in options (warrants) markets, the shorter (longer) settlement will be reflected in a downward (upward) price adjustment. A second implication of the different clearing procedures in the option and warrant markets is the role played by credit margins. In the options market, the Options Clearing House $(\mathrm{OCH})$ provides credit margins to option buyers, which may be used to offset debit margins.

\footnotetext{
${ }^{10}$ In a phone survey of 20 brokerage firms, accounting for $89 \%$ of equity trading value during the sample period, 17 also had DTF systems.
} 
Two considerations establish the relevance of minimum tick size. First, it affects price discreteness which has a direct price discovery impact, and second, it imposes a restriction on the size of the bid-ask spread. The minimum tick size influences the ability to make price adjustments. For example, if the price impact of the information content of a trade is less than the minimum tick size, the information will not immediately be incorporated into the price. The response to small changes in value is therefore constrained by the minimum tick size, and price discovery should occur more quickly in the market with the smallest minimum tick size.

The two markets are virtually indistinguishable when comparing tick size on an absolute basis. The minimum tick sizes in both markets are 0.1 cents for contracts priced up to 10 cents; 0.5 cents for contracts priced between 10 cents and 50 cents; and 1 cent for contracts priced over 50 cents. Additionally, SEATS sets a minimum tick size of $\$ 1$ for contracts priced over \$999.99. While Chan, Chung, and Johnson (1993) show the effects of different minimum tick sizes can be extremely important, they suggest that the minimum tick size as a percentage of asset value is a better measure from which to make comparisons. Since a conversion ratio is frequently involved in trading warrant contracts, they will often trade at a fraction of the price of comparable option contracts. Using percentage tick sizes, however, leads to the conclusion that the options market has a smaller minimum tick size than the warrants market, provided that the warrant series is traded with a conversion ratio greater than $1: 1$. In these cases, the options market is more attractive, and thus suggests that option prices will lead the warrant prices.

\footnotetext{
${ }^{11}$ The inability to shortsell a warrant is addressed later in the paper. Here we assume the seller of a
} 
Since bid and ask prices must be at least one tick apart, the greater the tick size, the greater the minimum bid-ask spread. In absolute terms no difference exists in the minimum spread between the markets, but the minimum percentage bid-ask spread in the options market is smaller than that of warrants for any series traded with a conversion ratio greater than 1:1. The bid-ask spread information reported in Table 1, Panel A shows that the quoted spreads in both markets are greater than the exchange mandated minimum tick sizes.

The options market allows investors to write or short sell option contracts, whereas investors in the warrants market are restricted to selling only those contracts previously purchased. This makes the trading of warrants more restrictive especially when information trades exert downward pressure on prices. A warrant trade could not be placed unless the trader had a previously established long position, and even in this situation they would be restricted to selling the number of contracts held.

Informed investors restricted from short selling warrant contracts may trade on their information in two ways. They may buy a warrant contract that features an inverse payoff function, such as buying a put warrant rather than short-selling a call warrant. ${ }^{12}$ Alternatively, the investor may choose to conduct a transaction in the options market, such as short-selling a call option since short-selling a call warrant is prohibited. The inability to short-sell warrant contracts is likely to render the options market more attractive, thereby inducing price discovery to occur more rapidly in the options market, and this effect is likely to be more pronounced in seller dominated markets.

\footnotetext{
derivative contract has an outstanding long position, which satisfies the sale.

${ }^{12}$ It can be argued that this alternative is rather unattractive to investors, as it requires them to substitute their intention to take a short position (receive a premium) with a long position (pay a premium).
} 
Both option and warrant contracts are legally binding agreements, between buyers and sellers. Each party, therefore, faces a certain degree of default risk, if the opposing party is not able to meet their obligations when they arise. By the very nature of derivative contracts, the credit risk of the buyer is nil, since they pay the purchase price of the contract (the premium). Default risk is therefore only applicable to the default of the seller. Although the ASX does not explicitly provide a guarantee to option holders, the National Guarantee Fund managed by a subsidiary of the ASX, guarantees the position held by all private investors in option contracts to a pre-specified limit. Furthermore, if the National Guarantee Fund proves insufficient, the ASX would likely meet any shortfalls, since the failure to guarantee positions would lead to destabilization of the market. Effectively, option contracts are default free.

The ASX, however, explicitly states that "neither the ASX nor its subsidiaries in any way guarantee the performance of the warrant issuer or the warrants issued.” Furthermore, the National Guarantee Fund plays no role in the protection of warrant holders. The ASX only determines and enforces the eligibility requirements that each issuer must meet in accordance with the ASX Business Rules. ${ }^{13}$ Although default risk is extremely low in the warrants market due to the strength and stability of the issuers, it is still possible.

Market makers facilitate options trading with each market maker committing to several obligations enforceable by the ASX. For each commitment, a market must be made on a continuous basis, for at least 12 option series ( 3 calls and 3 puts in each of the nearest

\footnotetext{
${ }^{13}$ The eligibility criteria set out in the ASX Business Rules include that an issuer must be subject to the Banking Act, or be a government, or have a securities dealers licence, an investment grade credit rating and sufficient net tangible assets, or have a guarantor that meets any of the above requirements.
} 
two expiry months). Hence, a bid quote and an ask quote must be provided at all times for these 12 option series. After a trade is executed, market makers have a period of 30 seconds to provide new quotes. Furthermore, market makers must make a market upon the receipt of a quote request for all series with an expiration of less than 9 months. Upon receipt of a quote request, the market maker must respond by providing a quote within a period of no more than 30 seconds. All quotes must be made for a minimum of either 5 or 10 contracts depending upon the classification, and the maximum bid-ask spread can not exceed 5 to 20 cents, again depending upon the classification. ${ }^{14}$

Market maker obligations in the warrants market are much less stringent. For example, each warrant issuer commits to making a market in his respective issues. These obligations are somewhat qualitative and subjective, and thus not strictly enforceable.

The differences in the institutional environment of these two informationally linked markets will affect their relative rates of price discovery. If the institutional environment associated with one market appears consistently more attractive to investors, then information should flow from the more attractive market. Given the preceding discussion, Table 4 provides a summary of the price lead/lag predictions based on institutional environment differences between the two markets. While the accessibility to the warrants market is greater than that of the options market, the relative attractiveness of each market based on settlement periods is inconclusive. All the other institutional differences indicate that the options market offers a more attractive trading environment and suggests a price relationship from options to warrants.

\footnotetext{
${ }^{14}$ Market maker obligations are set out in the ASX Procedures.
} 


\section{Methodology}

This study employs time series analysis and ordinary least squares regression (OLS) to investigate the price discovery process and the level of integration between the ASX Option and Warrant markets.

\section{Data considerations}

Implementation of the time series analysis considers price changes based on the midpoint of the quoted bid/ask spread instead of actual transaction prices. This eliminates and/or reduces the problems associated with the bid/ask bounce and price discreteness. ${ }^{15}$ Furthermore, using the quote midpoint significantly increases the sample size, which addresses the issue of non-synchronous trading.

Consistent with the price discovery literature each option and warrant series pairing is generated at five-minute intervals. ${ }^{16}$ For each security, the logarithm of the final quote midpoint from each interval is recorded and if no observation occurs within an interval, the previous observation is used. The warrants market is open between 10:00 am and 4:00 pm each day, while the options market opens at the same time, but closes at 4:15 pm. Additionally, in the options market a trading halt occurs between 12:30 pm and 2:00 pm each day. To ensure the accuracy of the price discovery results, it is essential that the analysis considers only periods when both markets are open. Thus the trading day is defined as the common open at 10:00 am until 12:30 pm, and from 2:00 pm until

\footnotetext{
${ }^{15}$ The quote midpoint effectively halves the tick size in each market.

${ }^{16}$ Fleming, Ostdiek, and Whaley (1996) identify that the five-minute interval is small enough to capture intra-day lead/lag relationships and long enough to avoid problems of non-synchronous data. Other studies using the five-minute interval include Stoll and Whaley (1990), Chan (1992), Chan, Chung and Johnson (1993), Kim et al. (1999), and O’Connor (1999).
} 
the warrants market closes at 4:00pm. ${ }^{17}$ Consequently, over the 65-day sample period there are a total of 54 five-minute intervals or 3,510 observations per firm.

\section{Unit root tests, cointegration and the error correction model}

Since the classical OLS regression model assumes that time series data is stationary, we test for unit roots and adjust the data appropriately to avoid spurious and inconsistent regression results. The unit root tests include the augmented Dickey-Fuller (ADF) (Dickey and Fuller, 1979) and Phillips Perron (PP) (Phillips and Perron, 1988) and are implemented as follows:

$$
\begin{aligned}
& \Delta \mathrm{Y}_{\mathrm{t}}=\delta \mathrm{Y}_{\mathrm{t}-1}+\sum_{i=1}^{n} \phi_{i} \Delta \mathrm{Y}_{\mathrm{t}-\mathrm{i}}+\varepsilon_{\mathrm{t}} \\
& \Delta \mathrm{Y}_{\mathrm{t}}=\alpha_{0}+\delta \mathrm{Y}_{\mathrm{t}-1}+\sum_{i=1}^{n} \phi_{i} \Delta \mathrm{Y}_{\mathrm{t}-\mathrm{i}}+\varepsilon_{\mathrm{t}} \\
& \Delta \mathrm{Y}_{\mathrm{t}}=\alpha_{0}+\delta \mathrm{Y}_{t-1}+\alpha_{2} t+\sum_{i=1}^{n} \phi_{\mathrm{i}} \Delta \mathrm{Y}_{\mathrm{t}-\mathrm{i}}+\varepsilon_{\mathrm{t}}
\end{aligned}
$$

where,

$\Delta \mathrm{Y}_{\mathrm{t}}$ represents the change in the option price (warrant price) between time $\mathrm{t}$ and $\mathrm{t}-1$,

$\mathrm{Y}_{\mathrm{t}-1}$ represents the option (warrant) price at time $\mathrm{t}-1$ and,

$\Delta \mathrm{Y}_{\mathrm{t}-\mathrm{i}}$ represents the lagged change in the option price (warrant price) and $\mathrm{i}=1, \ldots, \mathrm{n}$ lags.

Equation (1) represents a simple random walk (no intercept or trend term), equation (2) considers the series follows a random walk with a drift and thus includes an intercept term, and equation (3) specifies a random walk with a drift and a trend by including both an intercept and a trend term. We augment all three models with the lagged

\footnotetext{
${ }^{17}$ Since the time series analysis uses lagged variables, in order to avoid biased results, we exclude lagged observations from a previous day, lagged observations stretching across the daily trading halt period of
} 
changes of the dependent variable as explanatory variables where the optimal number of lags is determined by selecting the model that minimizes the Akaike Information Criterion (AIC) and the Schwartz Bayesian Criterion (SBC). When the null hypothesis, $\mathrm{H}_{0}: \delta=0$, or the existence of a unit root cannot be rejected, then the option (warrant) price series violates the OLS stationarity assumption. The hypotheses are evaluated using the critical statistics provided by MacKinnon (1991).

Next, cointegration is examined using the Engle and Granger (1987) approach to determine whether a long run equilibrium relation exists between option and warrant prices. This involves estimating the cointegrating relationship below using standard (OLS) techniques. ${ }^{18}$

$$
\mathrm{W}_{\mathrm{t}}=\beta_{0}+\beta_{1} \mathrm{O}_{\mathrm{t}}+\sum_{t=1}^{n} \Delta W_{t}+\varepsilon_{\mathrm{t}}
$$

or,

$$
\mathrm{O}_{\mathrm{t}}=\beta_{0}+\beta_{1} \mathrm{~W}_{\mathrm{t}}+\sum_{t=1}^{n} \Delta O_{t}+\varepsilon_{\mathrm{t}}
$$

where,

$\mathrm{W}_{\mathrm{t}}\left(\mathrm{O}_{\mathrm{t}}\right)$ represents the option (warrant) price at time $\mathrm{t}$

$\Delta \mathrm{W}_{\mathrm{t}}\left(\Delta \mathrm{O}_{\mathrm{t}}\right)$ represents the change in prices between time $\mathrm{t}-1$ and $\mathrm{t}$.

For each set of residuals, $\varepsilon_{t}$ from equations (4a) or (4b), equation (5) below is estimated separately for each series:

$$
\Delta \hat{e}_{t}=a_{1} \hat{e}_{t-1}+\varepsilon_{t}
$$

\footnotetext{
the options market and the extra 15 minutes of trading in the options market at the end of the day.

${ }^{18}$ As a robustness check, this test is performed separately for both the option and the warrant series as the dependent variable as specified in equations (4a) and (4b).
} 
Rejection of the null hypothesis, $\mathrm{H}_{0}$ : $\mathrm{a}_{1}=0$, based on the critical statistics from Engle and Granger (1987) indicates that the variables are cointegrated.

Finally, after confirming the nonstationarity of both the option and warrant price series and that a cointegrating relation exists, we analyze the price discovery process within the framework of an error correction model. With the price series being cointegrated, if there is a deviation from the long-run equilibrium of equal prices just prior to the start of trade in each market, a price correction will occur to move the markets back towards equilibrium. In practice, corrections result from arbitrage trading. For example, if the price of an option (warrant) series is too high relative to that of the directly comparable warrant (option) series, arbitrageurs will sell the option (warrant) and buy the warrant (option). The bivariate error-correction model follows:

$$
\begin{aligned}
& \Delta O_{t}=\alpha_{O} \hat{e}_{t-1}+\sum_{i=1}^{n} \gamma_{11}(i) \Delta W_{t-i}+\sum_{i=1}^{n} \gamma_{12}(i) \Delta O_{t-i}+\varepsilon o_{t} \\
& \Delta W_{t}=\alpha_{W} \hat{e}_{t-1}+\sum_{i=1}^{n} \gamma_{21}(i) \Delta W_{t-i}+\sum_{i=1}^{n} \gamma_{22}(i) \Delta O_{t-i}+\varepsilon w_{t}
\end{aligned}
$$

where,

$\Delta \mathrm{O}_{\mathrm{t}}\left(\Delta \mathrm{W}_{\mathrm{t}}\right)$ represents the change in the option (warrant) price between $\mathrm{t}-1$ and $\mathrm{t}$, $\Delta \mathrm{O}_{\mathrm{t}-\mathrm{i}}\left(\Delta \mathrm{W}_{\mathrm{t}-\mathrm{i}}\right)$ represents lagged option (warrant) price changes between $\mathrm{n}$ and $\mathrm{t}-1$, and

$\hat{e}_{t-1}$ represents the residuals estimated from the cointegrating equation (4a).

\section{Results}

The results of the Augmented-Dickey Fuller (ADF) and the Phillips Perron (PP) unit root tests are reported in Table 5. The Table includes the firm, the optimal number of 
lags for the model and the estimated $\delta$ coefficients for the price (levels) series and the differenced price series of both options and warrants. The ADF and PP tests indicate that the option and warrant price series are nonstationary, since the null hypothesis $(\delta=0)$ cannot be rejected at $5 \%$. Alternatively, the null hypothesis of a unit root can be rejected for the differenced prices of both options and warrants at the $1 \%$ level, indicating that the original nonstationary price series are integrated of order one, denoted as $I(1)$.

The Engle and Granger (1987) cointegration test results of regression equation (5) are reported in Table 6 . The $\mathrm{a}_{1}$ coefficient estimates and corresponding t-statistics are listed for each firm in the sample and for each price series with the option series (warrant series) as the dependent variable. The null hypothesis, $\mathrm{a}_{1}=0$, is rejected for each firm as all estimated t-statistics exceed the critical values. Thus, the option and warrant prices for each firm are cointegrated, that is, the residuals are stationary of order zero, denoted as $\mathrm{I}(0)$, and the two price series are linked by one long-run equilibrium relation.

While the cointegration equation holds in the long-run, there may be deviations from the equilibrium in the short-run. Further testing within an error-correction model (ECM) framework facilitates the examination of the error correction process, or pricing dynamics between the option and warrant markets when short-run deviations occur. The bi-variate ECM equations (6) and (7) provide estimates for two speed of adjustment terms, $\alpha_{0}$ and $\alpha_{W}$, measuring an immediate price response to the previous period's deviation from the long-run equilibrium. The inclusion of six lagged variables at fiveminute time intervals covering a thirty-minute period provide additional information 
regarding the length of time required to reestablish the equilibrium condition. ${ }^{19}$ Coefficient estimates for equations (6) and (7) are reported in Table 7.

The results support a bi-directional price relationship between the markets indicating that each market contributes to the price discovery process. The average speed of adjustment coefficients for the options market, $\alpha_{O}$, and the warrants market, $\alpha_{W}$, are 2.22 and 1.20 , respectively. While both of these average measurements are significantly different from zero, the speed of adjustment coefficient for the options market is almost two times that of the warrants market, and the difference between $\alpha_{O}$ and $\alpha_{W}$ are statistically significant (WRST). This suggests that the warrants market dominates and that the options market is more responsive to a deviation from the long-run equilibrium.

Further evidence in terms of individual firm speed of adjustment coefficient estimates also supports a warrants market lead as 15 of 19 options $\left(\alpha_{0}\right)$ estimates are significantly different from zero compared to 10 of 19 warrants $\left(\alpha_{\mathrm{w}}\right)$ estimates. This finding indicates that more of the options respond to a deviation from the long-run equilibrium relationship than do the warrants. Not only are option prices are more likely to respond to deviations from the implied long-run equilibrium condition, but the magnitude of the response is larger than in the case of the warrants market.

Analysis of the cross-coefficients, $\gamma_{12}$ and $\gamma_{21}$ also reinforces the bi-directional nature of the price discovery process in the two markets. For example, many of the lagged changes in the warrant (option) mid-quote series are statistically significant in

\footnotetext{
${ }^{19}$ To provide a consistent approach for all firms, the AIC and SBC are used to find the optimal number of lags in the aggregate, rather than on a firm specific basis.
} 
explaining the contemporaneous changes in the option (warrant) mid-quote series. However, as in the case of the speed of adjustment coefficient estimates, the lagged warrant price changes explain the contemporaneous option price changes for 16 of 19 sample firms, while the lagged changes in the option mid-quote series explain contemporaneous changes in the warrant price changes in only 10 of the 19 sample firms.

Overall, after considering both the speed of adjustment and the cross coefficient estimates, results indicate that in the price discovery process, the warrants market is the dominant market. Based on the trading cost hypothesis, the warrants market is more favorable than the options market, but the options market is more attractive according to the institutional environment hypothesis. The empirical results, therefore, suggest that trading costs have a greater impact on the price discovery process in these two markets.

Furthermore, on an individual basis, the findings for some firms contradict the general results. For example, in the case of Telstra (TLS) the warrant speed of adjustment estimate, $\left(\alpha_{w}\right)$, is significantly different from zero, while the option estimate, $\left(\alpha_{0}\right)$, is not. Additionally, the 10 and 15 minute option lags are significant in explaining the contemporaneous warrant price changes, while none of the warrant lags are significant in explaining the contemporaneous option price changes. While counter to the general findings of a bi-directional relationship, these results suggests that the options market strictly leads the warrants market in the price discovery process for this particular firm. In this case, the more favorable institutional environment factors of the options market outweigh the more favorable trading costs associated with the warrants market. 
This result suggests that there may be idiosyncratic features of firms that influence the importance of the competing price discovery hypotheses. Individual firm results serve to explain the coexistence of these two markets that for all intents and purposes trade redundant securities. The individual results support the existence of a clientele effect where under certain circumstances traders gravitate to the market with the lowest trading costs and at other times they look to the market with the most favorable institutional features.

\section{Summary and Conclusions}

This study investigates the pricing dynamics in the Australian option and warrant markets using an error correction model applied to intraday price series data. Findings indicate that the two markets are linked by the long-run equilibrium of price equality. Empirical results support bi-directional causality implying that both markets contribute to price discovery. Based on the relative magnitude of the speed of adjustment coefficients, however, the warrants market is dominant, thus suggesting that the impact of lower trading costs outweighs that of the institutional environment factors.

While general results indicate a dominant warrants market, differences may exist among individual firms. For example, we illustrate a case where the options market strictly leads the warrants market, thus supporting a clientele effect. The firm specific results suggest that the function of a trade may drive the market choice and thus impact the price discovery process. Time-varying market conditions may additionally impact the pricing dynamics when the institutional environment increases in importance. 
Since this study does not consider the market for the underlying assets of the derivative securities, a logical extension for future research would be to incorporate the underlying equity price series. This would capture a three-way relationship involving the equities market, the options market and the warrants market. The inclusion of a third market and the additional price series would introduce the leverage effect. Thus, after accounting for trading costs and the institutional environment factors holding leverage constant via the option and warrant markets, the equity market price series may provide the information needed to test the leverage hypothesis. 


\section{References}

Abyankar, A.H., 1995, Return and volatility dynamics in the FT-SE 100 stock index and stock index futures markets, Journal of Futures Markets, 4, 457-488.

Anthony, J., 1988, The Intercorrelation of Stock and Options Market Trading-Volume Data, Journal of Finance 43, 949-964.

Black, F., 1975, Fact and Fantasy in use of options, Financial Analysts Journal 31, 3641,61-72.

Bhattacharya, M., 1987, Price Changes of Related Securities: The Case of Call Options and Stocks, Journal of Finance and Quantitative Analysis 22, 1-15.

Cao, H., 1999, The Effect of Derivative Assets on Information Acquisition and Price Behaviour in a Rational Expectations Equilibrium, The Review of Financial Studies 12, 131-163.

Chan, K., 1992, A Further Analysis of the Lead-Lag Relationship Between the Cash Market and Stock Index Futures Market, Review of Financial Studies 5, 123-152.

Chan, K., 1993, Imperfect Information and Cross-Autocorrelation Among Stock Prices, Journal of Finance 48, 1211-1230.

Chan, K., P. Chung, and H. Johnson, 1993, Why Option Prices Lag Stock Prices: A Trading-Based Explanation, Journal of Finance 48, 1957-1967.

Chan, K., K.C. Chan, and K. Karolyi, 1991, Intraday Volitility in the Stock Index and Stock Index Futures Market, Review of Financial Studies 4, 657-684.

Chu, Q., W. Hsieh, and Y. Tse, 1999, Price Discovery on the S\&P 500 Index Markets: An Analysis of Spot Index, Index Futures and SPDRs, International Review of Financial Analysis 8, 21-34. 
Copeland, T.E., 1976, A model of asset trading under the assumption of sequential information arrival, Journal of Finance 31, 1149-1168.

Easley, D., M. O’Hara, and P. Srinivas, 1988, Option Volume and Stock Prices:

Evidence on where Informed Traders Trade, Journal of Finance 53, 431-465.

Eun, C.S., and S. Shim, 1989, International transmission of stock market movements, Journal of Financial and Quantitative Analysis, 2, 241-256.

Fleming, J., B. Ostdiek, and R. Whaley, 1996, Trading Costs and the Relative Rates of Price Discovery in Stock, Futures, and Options Markets, Journal of Futures Markets 16, 353-387.

Garbade, K., and W. Silber, 1979, Dominant and Satellite Markets: A Study of DuallyTraded Securities, Review of Economics and Statistics 61, 455-460.

Harris, F., T. McInish, G. Shoesmith, and R. Wood, 1995, Cointegration, Error Correction, and Price Discovery on Informationally Linked Security Markets, Journal of Financial and Quantitative Analysis 30, 563-579.

Hasbrouck, J., 1995, One Security, Many Markets: Determining the Contribution to Price Discovery, Journal of Finance 50, 1175-1199.

He, L., 1997, Price Discovery in the Hong Kong Security Markets: Evidence from Cointegration Tests, Journal of International Financial Markets, Institutions and Money 7, 157-169.

Kawaller, I., P. Koch, and T. Koch, 1993, Intraday Market Behaviour and the Extent of Feedback Between S\&P 500 Futures Prices and the S\&P 500 Index, Journal of Financial Research 14, 107-121. 
Kim, M., A. Szakmary, and T. Schwarz, 1999, Trading Costs and Price Discovery Across Stock Index Futures and Cash Markets, The Journal of Futures Markets 19(4), 475-498.

Kumar, R., and K. Shastri, 1990, The Predictive Ability of Stock Prices Implied in Option Premia, Advanced in Futures and Options Research 4, 165-170.

Manaster, S., and R. Rendleman, 1982, Option Prices as Predictors of Equilibrium Stock Prices, Journal of Finance 37, 1043-1057.

O’Connor, M., 1999, The Cross-Sectional Relationship Between Trading Costs and Lead/Lag Effects in Stock and Option Markets, The Financial Review 34, 95-118.

Stephan, J., and R. Whaley, 1990, Intraday Price Change and Trading Volume Relations in the Stock and Stock Option Markets, Journal of Finance 45, 191-220.

Stoll, H., and R. Whaley, 1990, The Dynamics of Stock Index and Stock Futures Returns, Journal of Financial and Quantitative Analysis 25, 441-468.

Vijh, A., 1990, Liquidity of the CBOE Equity Options, Journal of Finance 45, 1157 1179. 
Table 1

\section{Panel A}

Bid-Ask Spread Measures for the Option and Warrant Markets

This table presents the bid-ask spread measures in both absolute and percentage terms for the option

series and warrant series for each firm included in the sample from September 1 to November 30, 1999.

\begin{tabular}{|c|c|c|c|c|c|c|c|c|}
\hline Firm & $\begin{array}{l}\text { Options } \\
\text { Quoted } \\
\text { Bid-ask Spread }\end{array}$ & $\begin{array}{l}\text { \% Quoted } \\
\text { Bid-ask Spread }\end{array}$ & $\begin{array}{l}\text { Effective } \\
\text { Bid-ask Spread }\end{array}$ & $\begin{array}{l}\text { \% Effective } \\
\text { Bid-ask Spread }\end{array}$ & $\begin{array}{l}\text { Warrants } \\
\text { Quoted } \\
\text { Bid-ask Spread }\end{array}$ & $\begin{array}{l}\text { \% Quoted } \\
\text { Bid-ask Spread }\end{array}$ & $\begin{array}{l}\text { Effective } \\
\text { Bid-ask Spread }\end{array}$ & $\begin{array}{l}\text { \% Effective } \\
\text { Bid-ask Spread }\end{array}$ \\
\hline$\overline{\mathrm{BHP}^{\mathbf{b}}}$ & 0.0440 & $69.20 \%$ & 0.0271 & $48.72 \%$ & 0.0310 & $52.12 \%$ & 0.0206 & $37.33 \%$ \\
\hline $\mathrm{CBA}^{\mathrm{c}}$ & 0.1798 & $13.11 \%$ & 0.1412 & $9.29 \%$ & 0.0198 & $6.39 \%$ & 0.0136 & $4.41 \%$ \\
\hline $\mathrm{CGH}^{\mathrm{a}}$ & 0.0601 & $51.06 \%$ & 0.0361 & $30.15 \%$ & 0.0185 & $50.28 \%$ & 0.0123 & $38.47 \%$ \\
\hline CWO & 0.0382 & $17.81 \%$ & 0.0235 & $11.30 \%$ & 0.0191 & $6.73 \%$ & 0.0120 & $4.28 \%$ \\
\hline $\mathrm{FBG}^{\mathrm{a}}$ & 0.0666 & $17.33 \%$ & 0.0433 & $10.97 \%$ & 0.0181 & $10.06 \%$ & 0.0162 & $8.93 \%$ \\
\hline LHG & 0.0369 & $35.26 \%$ & 0.0185 & $16.87 \%$ & 0.0096 & $7.62 \%$ & 0.0072 & $5.69 \%$ \\
\hline $\mathrm{NAB}^{\mathrm{a}}$ & 0.0734 & $9.89 \%$ & 0.0359 & $4.93 \%$ & 0.0240 & $6.91 \%$ & 0.0152 & $4.53 \%$ \\
\hline NCM & 0.0571 & $13.24 \%$ & 0.0348 & $8.41 \%$ & 0.1211 & $15.78 \%$ & 0.0554 & $7.37 \%$ \\
\hline $\mathrm{NCP}^{\mathrm{c}}$ & 0.0686 & $7.94 \%$ & 0.0395 & $4.82 \%$ & 0.0159 & $6.20 \%$ & 0.0101 & $4.15 \%$ \\
\hline $\mathrm{OSH}$ & 0.0543 & $32.58 \%$ & 0.0271 & $15.49 \%$ & 0.0206 & $9.54 \%$ & 0.0126 & $6.05 \%$ \\
\hline PAS & 0.0325 & $21.76 \%$ & 0.0176 & $11.65 \%$ & 0.0089 & $5.78 \%$ & 0.0065 & $4.15 \%$ \\
\hline PDP & 0.0397 & $88.54 \%$ & 0.0186 & $47.99 \%$ & 0.0194 & $11.61 \%$ & 0.0113 & $6.81 \%$ \\
\hline $\mathrm{SGB}^{\mathrm{a}}$ & 0.0606 & $26.56 \%$ & 0.0350 & $15.11 \%$ & 0.0308 & $12.65 \%$ & 0.0198 & $8.28 \%$ \\
\hline STO & 0.0384 & $19.67 \%$ & 0.0206 & $10.79 \%$ & 0.0282 & $10.24 \%$ & 0.0193 & $6.90 \%$ \\
\hline $\operatorname{TLS}^{\mathbf{a}}$ & 0.0507 & $73.57 \%$ & 0.0243 & $35.44 \%$ & 0.0093 & $24.49 \%$ & 0.0079 & $22.38 \%$ \\
\hline $\mathrm{WBC}^{\mathrm{a}}$ & 0.0588 & $19.49 \%$ & 0.0312 & $10.38 \%$ & 0.0227 & $11.11 \%$ & 0.0126 & $6.41 \%$ \\
\hline $\mathrm{WMC}^{\mathbf{a}}$ & 0.0730 & $14.69 \%$ & 0.0288 & $6.30 \%$ & 0.0357 & $8.12 \%$ & 0.0207 & $4.86 \%$ \\
\hline WOW $^{\mathrm{a}}$ & 0.0625 & $23.19 \%$ & 0.0291 & $10.50 \%$ & 0.0209 & $9.84 \%$ & 0.0126 & $6.17 \%$ \\
\hline $\mathrm{WPL}^{\mathbf{b}}$ & 0.0859 & $20.08 \%$ & 0.0509 & $12.26 \%$ & 0.0152 & $6.57 \%$ & 0.0113 & $4.85 \%$ \\
\hline Average & 0.0622 & $30.26 \%$ & 0.0360 & $16.91 \%$ & 0.0257 & $14.32 \%$ & 0.0156 & $10.11 \%$ \\
\hline $\begin{array}{l}\text { WSRT z-st } \\
\operatorname{Pr}<\text { z }\end{array}$ & $\begin{array}{r}4.70 \\
<.0001\end{array}$ & $\begin{array}{r}3.45 \\
0.0003\end{array}$ & $\begin{array}{c}4.38 \\
<0.0001\end{array}$ & $\begin{array}{l}2.96 \\
0.0015\end{array}$ & & & & \\
\hline
\end{tabular}

${ }^{a}$ Associated warrant has a conversion ratio of 2:1. ${ }^{\mathrm{b}}$ Associated warrant has a conversion ratio of 3:1. ${ }^{\mathrm{c}}$ Associated warrant has a conversion ratio of 4:1. 
Table 1

\section{Panel B}

\section{Market Liquidity Measures for the Option and warrant markets}

Liquidity measures in share equivalents for the option series and warrant series for each firm from September 1 to November 30, 1999.

For options, the share equivalent is 1,000 times the number of contracts. For warrants, it is the number of contracts divided by the conversion ratio.

\begin{tabular}{|c|c|c|c|c|c|c|c|c|}
\hline Firm & $\begin{array}{l}\text { Options } \\
\text { Average } \\
\text { Bid Depth }\end{array}$ & $\begin{array}{l}\text { Average } \\
\text { Ask Depth }\end{array}$ & $\begin{array}{l}\text { Average } \\
\text { Daily Volume }\end{array}$ & $\begin{array}{c}\text { Average } \\
\text { Trans. Size }\end{array}$ & $\begin{array}{l}\text { Warrants } \\
\text { Average } \\
\text { Bid Depth }\end{array}$ & $\begin{array}{l}\text { Average } \\
\text { Ask Depth }\end{array}$ & $\begin{array}{l}\text { Average } \\
\text { Daily Vol. }\end{array}$ & $\begin{array}{l}\text { Average } \\
\text { Trans. Size }\end{array}$ \\
\hline$\overline{\mathrm{BHP}^{\mathbf{b}}}$ & 10421.80 & 14301.10 & 21419.76 & 12321.10 & 12660.53 & 12338.83 & 8271.98 & 6806.06 \\
\hline $\mathrm{CBA}^{\mathrm{c}}$ & 10931.70 & 10636.60 & 7469.29 & 8216.22 & 5805.99 & 5807.20 & 25063.02 & 2980.47 \\
\hline $\mathrm{CGH}^{\mathrm{a}}$ & 15721.40 & 15817.30 & 9795.46 & 35916.70 & 15840.06 & 17486.59 & 21870.25 & 9252.80 \\
\hline CWO & 48905.70 & 43852.50 & 231173.95 & 58241.50 & 19118.08 & 17308.10 & 62853.12 & 12417.79 \\
\hline $\mathrm{FBG}^{\mathrm{a}}$ & 22906.90 & 32662.30 & 409.09 & 6000.00 & 14880.76 & 15585.53 & 13488.34 & 6118.42 \\
\hline LHG & 30310.60 & 26128.00 & 61711.86 & 55712.10 & 44020.71 & 44440.35 & 267699.50 & 21455.57 \\
\hline $\mathrm{NAB}^{\mathrm{a}}$ & 12681.60 & 12918.60 & 51355.98 & 11708.10 & 7493.03 & 8383.10 & 107039.28 & 5527.85 \\
\hline NCM & 12848.70 & 12403.60 & 5015.39 & 19176.50 & 11485.69 & 11383.23 & 13009.24 & 9948.24 \\
\hline $\mathrm{NCP}^{\mathrm{c}}$ & 18421.90 & 12207.00 & 40281.62 & 63861.10 & 10170.45 & 10448.77 & 41931.31 & 4232.20 \\
\hline $\mathrm{OSH}$ & 11177.90 & 11784.50 & 20871.54 & 31550.00 & 24452.20 & 28077.71 & 30697.78 & 12790.74 \\
\hline PAS & 15610.30 & 13217.80 & 62717.92 & 52943.70 & 54043.61 & 63323.30 & 309610.12 & 20747.07 \\
\hline PDP & 14803.20 & 18120.50 & 846.15 & 18333.30 & 16000.91 & 16500.29 & 1554.66 & 16842.17 \\
\hline $\mathrm{SGB}^{\mathrm{a}}$ & 9834.45 & 9999.47 & 17661.13 & 13195.10 & 11880.21 & 11743.03 & 5930.52 & 5840.66 \\
\hline STO & 19457.30 & 16981.30 & 14068.28 & 14288.10 & 22440.31 & 23349.96 & 14350.75 & 11516.03 \\
\hline $\mathrm{TLS}^{\mathbf{a}}$ & 25169.30 & 15681.00 & 127812.12 & 109313.00 & 29571.30 & 15346.38 & 177456.55 & 10391.60 \\
\hline $\mathrm{WBC}^{\mathbf{a}}$ & 12593.10 & 11901.40 & 5801.28 & 7541.67 & 8959.36 & 10218.96 & 20997.00 & 9221.66 \\
\hline $\mathrm{WMC}^{\mathrm{a}}$ & 14199.10 & 14207.10 & 37476.92 & 60900.00 & 24816.05 & 24613.39 & 14819.16 & 10247.29 \\
\hline WOW $^{\mathrm{a}}$ & 10500.40 & 9772.02 & 12872.44 & 25354.80 & 18116.78 & 19108.55 & 4343.43 & 10456.41 \\
\hline WPL $^{\mathbf{b}}$ & 11428.60 & 10788.50 & 12553.83 & 38857.10 & 11495.73 & 9289.44 & 18414.43 & 5782.31 \\
\hline Average & 17259.16 & 16493.72 & 39016.53 & 33864.74 & 19118.51 & 19197.51 & 61021.08 & 10135.54 \\
\hline WSRT z-stat & & & & & 0.2919 & 0.2628 & 0.7883 & -3.5618 \\
\hline $\operatorname{Pr}<\mathrm{z}$ & & & & & 0.3852 & 0.3964 & 0.2153 & 0.0002 \\
\hline
\end{tabular}




\section{Table 2}

\section{Explicit Transaction Costs for the Options and Warrants Markets}

This table shows both the variable and fixed transaction costs charged by the ASX for option and warrant contracts. Fees do not include GST. ${ }^{\text {a }}$

\section{Options}

\begin{tabular}{lrl}
\hline Description & Cost & Method of Calculation \\
\hline Variable Costs & & \\
$\quad$ Registration Fee & $\$ 1.02^{\text {b }}$ & Per traded contract \\
Option Exercise Fee & $\$ 0.50$ & Per exercised contract \\
Single Enquiry Fee & $\$ 0.01$ & Per enquiry \\
& & \\
Fixed Costs & & \\
$\quad$ Market Services & $\$ 440.00$ & \\
$\quad$ Market Access and Networks & $\$ 27,939.96$ & \\
\hline
\end{tabular}

\section{Warrants}

\begin{tabular}{|c|c|c|}
\hline Description & Cost & Method of Calculation \\
\hline \multicolumn{3}{|l|}{ Variable Costs } \\
\hline Trade Value & $\$ 2.00^{\mathrm{c}}$ & Per $\$ 100,000$ \\
\hline Per Order & $\$ 0.19$ & Per order placed \\
\hline Broker / Broker SEAT Trade Settlement & $\$ 1.10^{\mathrm{d}}$ & Per trade \\
\hline Off Market CHESS to CHESS Transfer & $\$ 0.50$ & Per exercised contract \\
\hline Single Enquiry Fee & $\$ 0.01$ & Per enquiry \\
\hline \multicolumn{3}{|l|}{ Fixed Costs } \\
\hline Market Services & $\$ 685.00$ & \\
\hline Market Access and Networks & $\$ 23,910.00$ & \\
\hline \multicolumn{3}{|c|}{$\begin{array}{l}\text { a The information source is the ASX Schedule of Fees - Market Services and the ASX Schedule of Fees - Market } \\
\text { Access and Networks. } \\
\text { b A market maker receives a concession with regard to the registration fee. Their cost is equal to } \$ 0.19 \text {. } \\
\text { c Fee is capped at } \$ 15.00 \text {. } \\
\text { d Fee concessions are available if monthly trading volume is high. The benchmark fee of } \$ 1.10 \text { is reduced if the } \\
\text { trading volume for a month is greater than } 40,000 \text { trades. At } 120,000 \text { trades a maximum concession of } 35 \% \text { is } \\
\text { applicable. Between } 40,000 \text { and } 120,000 \text { trades, the concession is linearly interpolated. }\end{array}$} \\
\hline
\end{tabular}


Table 3

Trading Cost Summary and Lead/Lag Predictions

Trading Costs

Bid-Ask Spread:

Quoted

Percentage

Effective

Percentage effective

Liquidity:

Depth

Volume

Size

Explicit Transaction Costs:

Setup and fixed costs

Variable costs
Lead/Lag

Warrants lead options

Warrants lead options

Warrants lead options

Warrants lead options

Inconclusive

Inconclusive

Options lead warrants

Inconclusive

Warrants lead options 


\section{Table 4}

Institutional Environment Summary and Lead/Lag Predictions

\begin{tabular}{ll}
\hline Institutional Difference & Lead/Lag \\
\hline $\begin{array}{l}\text { Trading Systems } \\
\text { Market Accessibility } \\
\text { Functionality }\end{array}$ & $\begin{array}{l}\text { Warrants lead options } \\
\text { Options lead warrants }\end{array}$ \\
$\begin{array}{l}\text { Clearing Systems } \\
\text { Settlement Period }\end{array}$ & $\begin{array}{l}\text { Inconclusive } \\
\text { Margin Requirements }\end{array}$ \\
Tick Size & Options lead warrants \\
Short-Sell Restrictions & Options lead warrants * \\
Default Risk & Options lead warrants \\
Market Maker Obligations & Options lead warrants \\
\hline
\end{tabular}

* Indicates that the prediction relies on a conversion ratio greater than 1:1. 


\section{Table 5}

\section{Unit Root Tests in the Options Market and in the Warrants Market}

This table presents the results of the unit root tests for both the option and warrant price series. It includes firm, optimal number of lags (determined by minimizing the AIC and the SBC) and, ADF and PP levels and differenced $\delta$ coefficients with significance annotated.

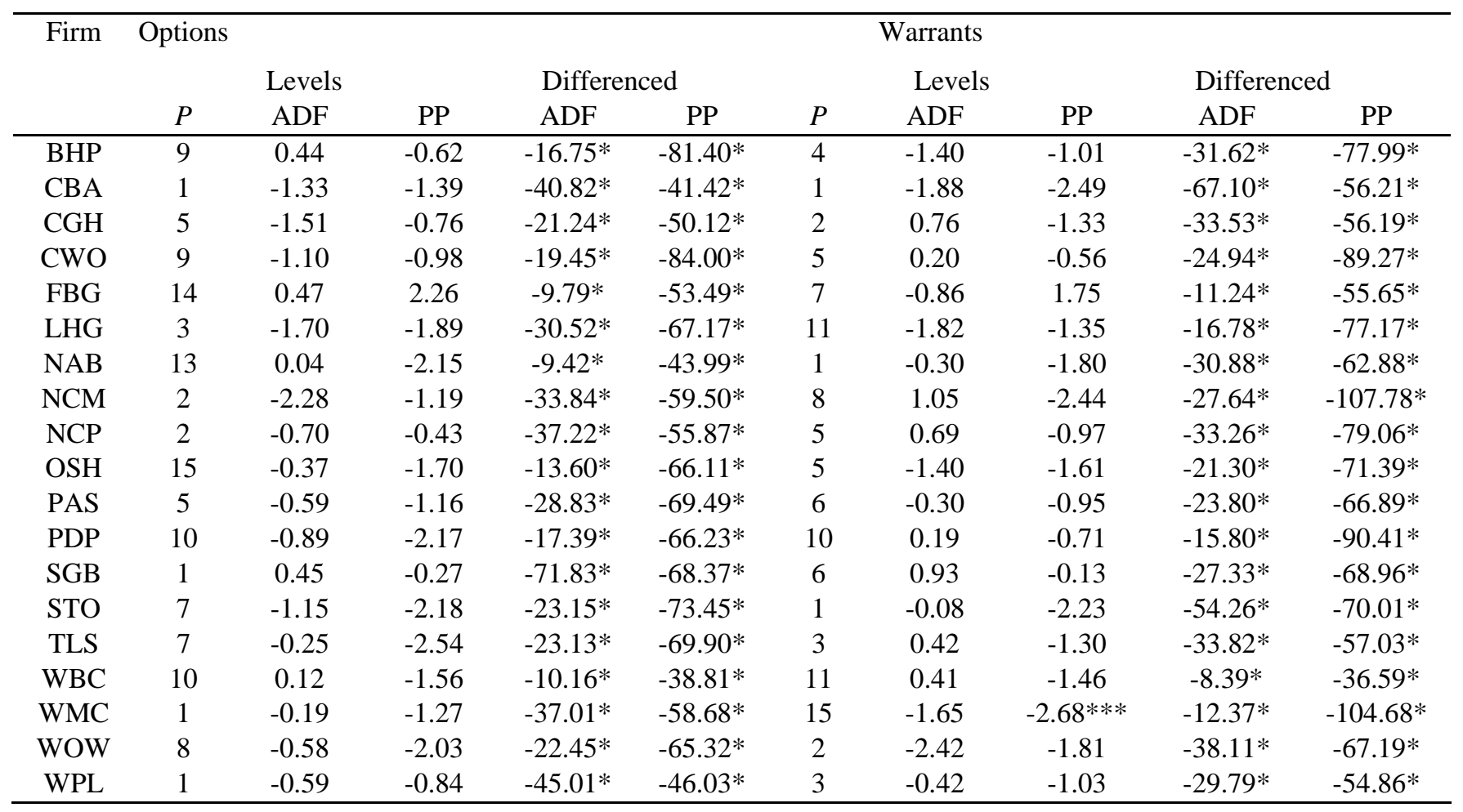

Significance levels are based on the MacKinnon (1991), where the asymptotic critical values at the $1 \%, 5 \%$ and $10 \%$ levels of significance are $-3.43,-2.86$ and -2.57 , respectively.

$*=1 \%$,

$* *=5 \%$

$* * *=10 \%$ 


\section{Table 6}

\section{Cointegration Tests}

This table presents the results of the Engle and Granger (1987) cointegration test. For each firm, the cointegrating relationship is calculated twice, once using the differenced option price series $(\Delta \mathrm{O})$ as the dependent variable, and once using the differenced warrant price series $(\Delta \mathrm{W})$ as the dependent variable. The coefficient value and t-statistic (in parentheses), are estimated from the regression: $\Delta \hat{e}_{t}=a_{1} \hat{e}_{t-1}+\varepsilon_{t}$

\begin{tabular}{lcc}
\hline Firm & \multicolumn{2}{c}{$\mathbf{a}_{\mathbf{1}}$} \\
& $\Delta \mathrm{O}$ & $\Delta \mathrm{W}$ \\
\hline BHP & -0.04033 & -0.04068 \\
& $(-8.16)$ & $(-8.21)$ \\
CBA & -0.04297 & -0.04998 \\
& $(-6.27)$ & $(-6.81)$ \\
CGH & -0.07975 & -0.08112 \\
& $(-9.57)$ & $(-6.81)$ \\
CWO & -0.1198 & -0.11892 \\
& $(-14.93)$ & $(-14.88)$ \\
FBG & -0.10331 & -0.10362 \\
& $(-11.07)$ & $(-11.10)$ \\
LHG & -0.04146 & -0.0411 \\
& $(-8.64)$ & $(-8.60)$ \\
NAB & -0.04235 & -0.04225 \\
& $(-6.17)$ & $(-6.15)$ \\
NCM & -0.03307 & -0.04571 \\
& $(-7.45)$ & $(-8.78)$ \\
NCP & -0.08475 & -0.08674 \\
& $(-11.85)$ & $(-12.00)$ \\
OSH & -0.1014 & -0.10112 \\
& $(-13.68)$ & $(-13.66)$ \\
PAS & -0.08758 & -0.08705 \\
& $(-12.68)$ & $(-12.64)$ \\
PDP & -0.03369 & -0.03147 \\
& $(-6.62)$ & $(-6.29)$ \\
SGB & -0.15477 & -0.15497 \\
& $(-17.1)$ & $(-17.13)$ \\
STO & -0.21232 & -0.21168 \\
& $(-20.40)$ & $(-20.37)$ \\
TLS & -0.03292 & -0.02842 \\
& $(-7.42)$ & $(-6.85)$ \\
WBC & -0.07612 & -0.07447 \\
& $(-6.99)$ & $(-6.9)$ \\
WMC & -0.13302 & -0.147 \\
& $(-15.29)$ & $(-16.13)$ \\
WOW & -0.03213 & -0.03149 \\
& $(-7.3)$ & $(-7.22)$ \\
WPL & -0.02335 & -0.02431 \\
& $(-4.97)$ & $(-5.07)$ \\
\hline & & \\
& &
\end{tabular}

The critical values from Engle and Granger (1987) indicate that all estimates are significant at the $1 \%$ level. 
Table 7

\section{Error Correction Model Results}

This table presents the results from the estimation of the error-correction model. The estimated model is:

$\Delta O_{t}=\alpha_{0} \hat{e}_{t-1}+\sum_{i=1}^{n} \gamma_{11}(i) \Delta W_{t-i}+\sum_{i=1}^{n} \gamma_{12}(i) \Delta O_{t-i}+\varepsilon_{0 t}$

$\Delta W_{t}=\alpha_{w} \hat{e}_{t-1}+\sum_{i=1}^{n} \gamma_{21}(i) \Delta W_{t-i}+\sum_{i=1}^{n} \gamma_{22}(i) \Delta O_{t-i}+\varepsilon_{w}$

The error-correction model is estimated for each option and warrant series pairing considering five-minute interval mid-quote data. Each lag

is equal to a five-minute period and number of lags is determined by minimizing the AIC and SBC. Adjustments are made to eliminate the effects

of differences in trading hours between the option and warrant markets. The critical t-statistic at the $5 \%$ level of significance is 1.96 .

\begin{tabular}{|c|c|c|c|c|c|c|c|c|c|c|c|c|c|c|}
\hline \multicolumn{3}{|c|}{ Dep } & \multicolumn{6}{|c|}{ Option Lags } & \multicolumn{6}{|c|}{ Warrant Lags } \\
\hline Firm & Var & Alpha & $-5 \min$ & $-10 \min$ & $-15 \min$ & $-20 \min$ & $-25 \min$ & $-30 \min$ & $-5 \min$ & $-10 \min$ & $-15 \min$ & $-20 \min$ & $-25 \min$ & $-30 \min$ \\
\hline \multirow[t]{4}{*}{$\overline{\mathrm{BHP}}$} & $\mathrm{O}$ & 213 & -0.43152 & -0.13985 & -0.10698 & -0.07532 & 0.02573 & 0.0008743 & 13711 & 0.10943 & 0.09238 & 0.08625 & .04389 & 0.01433 \\
\hline & & 3.7 & -20.22 & -6.15 & -4.7 & -3.32 & 1.16 & 0.04 & 4.82 & 3.65 & 3.06 & 2.84 & 1.47 & 0.51 \\
\hline & $\mathrm{W}$ & .00778 & 0.0515 & 0.04005 & 0.03815 & 0.03142 & 0.04401 & 0.02882 & -0.34453 & -0.1286 & -0.02734 & -0.04017 & -0.02681 & -0.00608 \\
\hline & & -2.06 & 3.68 & 2.69 & 2.56 & 2.11 & 3.02 & 2.24 & -18.47 & -6.54 & -1.38 & -2.02 & -1.37 & -0.33 \\
\hline \multirow[t]{4}{*}{ CBA } & $\mathrm{O}$ & 0.0154 & -0.0031 & -0.00353 & -0.07287 & -0.01623 & 0.0073 & 0.00117 & 0.08463 & 0.10022 & 0.08038 & 0.05314 & 0.05908 & 0.06189 \\
\hline & & 2.56 & -0.13 & -0.15 & -2.92 & -0.68 & 0.31 & 0.05 & 4.08 & 4.6 & 3.65 & 2.42 & 2.72 & 3.01 \\
\hline & W & -0.01589 & 0.05975 & 0.02118 & -0.0082 & 0.03135 & -0.01526 & 0.03154 & -0.28208 & -0.08447 & -0.06581 & -0.00217 & 0.03092 & 0.03191 \\
\hline & & -2.7 & 2.53 & 0.89 & -0.34 & 1.33 & -0.65 & 1.36 & -13.89 & -3.96 & -3.06 & -0.1 & 1.45 & 1.59 \\
\hline \multirow[t]{4}{*}{ CGH } & $\mathrm{O}$ & 0.03015 & -0.07231 & -0.00927 & 0.00917 & 0.03993 & -0.03445 & 0.00685 & -0.05501 & -0.00686 & 0.01585 & 0.01794 & -0.00273 & -0.03167 \\
\hline & & 5.19 & -3.11 & -0.41 & 0.4 & 1.85 & -1.64 & 0.32 & -2.25 & -0.29 & 0.66 & 0.86 & -0.16 & -1.93 \\
\hline & W & -0.00769 & 0.05035 & 0.01239 & 0.02318 & 0.00879 & 0.01521 & 0.01339 & -0.1503 & -0.0105 & -0.01485 & 0.01791 & 0.00088 & -0.00668 \\
\hline & & -1.32 & 2.17 & 0.54 & 1.02 & 0.41 & 0.72 & 0.63 & -6.16 & -0.44 & -0.62 & 0.86 & 0.05 & -0.41 \\
\hline \multirow[t]{4}{*}{ CWO } & $\mathrm{O}$ & 0.05532 & -0.3788 & -0.20721 & -0.12244 & -0.0718 & -0.03806 & -0.0128 & 0.17668 & 0.00571 & 0.17836 & 0.13451 & 0.08637 & 0.07148 \\
\hline & & 4.64 & -17.41 & -8.8 & -5.14 & -3.08 & -1.7 & -0.63 & 3.13 & 0.1 & 3.06 & 2.32 & 1.56 & 1.35 \\
\hline & W & -0.01446 & 0.00952 & 0.01259 & 0.00668 & 0.002 & 0.00517 & 0.00401 & -0.23118 & -0.16839 & -0.07026 & 0.0151 & -0.0019 & 0.02558 \\
\hline & & -3.25 & 1.17 & 1.44 & 0.75 & 0.23 & 0.62 & 0.53 & -10.99 & -7.88 & -3.24 & 0.7 & -0.09 & 1.3 \\
\hline
\end{tabular}




\section{Table 7}

\section{Error Correction Model Results (cont'd)}

\begin{tabular}{|c|c|c|c|c|c|c|c|c|c|c|c|c|c|c|}
\hline \multicolumn{3}{|c|}{ Dep } & \multicolumn{6}{|c|}{ Option Lags } & \multicolumn{6}{|c|}{ Warrant Lags } \\
\hline Firm & Var & Alpha & $-5 \min$ & $-10 \min$ & $-15 \min$ & $-20 \min$ & $-25 \min$ & $-30 \min$ & $-5 \min$ & $-10 \min$ & $-15 \min$ & $-20 \min$ & $-25 \min$ & $-30 \min$ \\
\hline \multirow[t]{4}{*}{$\overline{\text { FBG }}$} & $\mathrm{O}$ & 0.02514 & -0.12202 & 0.00721 & 0.00986 & 0.00359 & -0.11737 & -0.06528 & -0.01192 & -0.03003 & 0.0416 & 0.09178 & 0.0268 & 0.1124 \\
\hline & & 2.83 & -4.39 & 0.26 & 0.33 & 0.12 & -3.99 & -2.2 & -0.36 & -0.9 & 1.3 & 2.84 & 0.85 & 3.62 \\
\hline & W & -0.0522 & 0.01777 & 0.01909 & 0.0277 & 0.0318 & 0.02215 & 0.04056 & 0.14056 & 0.12076 & -0.0764 & 0.01048 & 0.03913 & 0.10389 \\
\hline & & -6.15 & 0.67 & 0.72 & 0.96 & 1.1 & 0.79 & 1.43 & 4.48 & 3.77 & -2.5 & 0.34 & 1.29 & 3.49 \\
\hline \multirow[t]{4}{*}{ LHG } & $\mathrm{O}$ & 0.01425 & -0.14984 & -0.02955 & -0.06591 & -0.03719 & 0.0011 & -0.00216 & 0.03435 & 0.04897 & 0.10963 & 0.03291 & 0.039 & 0.02302 \\
\hline & & 3.05 & -6.72 & -1.35 & -3.25 & -1.87 & 0.06 & -0.12 & 0.9 & 1.26 & 3.14 & 1.03 & 1.28 & 0.81 \\
\hline & W & -0.00327 & 0.0319 & 0.01485 & -0.01743 & -0.00263 & 0.00409 & -0.000121 & -0.25663 & -0.05535 & -0.07697 & -0.05595 & -0.01668 & 0.01493 \\
\hline & & -1.19 & 2.43 & 1.15 & -1.46 & -0.22 & 0.36 & -0.01 & -11.48 & -2.43 & -3.75 & -2.98 & -0.93 & 0.9 \\
\hline \multirow[t]{4}{*}{ NAB } & $\mathrm{O}$ & -0.0016 & -0.21666 & -0.13662 & -0.00703 & -0.02109 & -0.01261 & 0.03499 & 0.14 & 0.15377 & 0.03815 & 0.0079 & 0.01157 & 0.02381 \\
\hline & & -0.46 & -6.42 & -3.86 & -0.2 & -0.64 & -0.42 & 1.23 & 3.99 & 4.08 & 1.01 & 0.24 & 0.4 & 0.98 \\
\hline & W & 0.00309 & 0.16305 & 0.07328 & 0.06075 & 0.03177 & 0.00364 & -0.0084 & -0.22516 & -0.01639 & -0.10002 & -0.05504 & -0.03149 & 0.01569 \\
\hline & & 0.74 & 4.05 & 1.73 & 1.46 & 0.8 & 0.1 & -0.25 & -5.38 & -0.36 & -2.22 & -1.38 & -0.9 & 0.54 \\
\hline \multirow[t]{4}{*}{ NCM } & $\mathrm{O}$ & 0.00294 & -0.0112 & 0.01779 & -0.02106 & 0.01337 & -0.00066 & 0.0064 & 0.00271 & 0.00412 & 0.00059 & -0.00615 & -0.00018 & 0.00549 \\
\hline & & 2.02 & -0.54 & 0.86 & -1.03 & 0.67 & -0.04 & 0.43 & 0.31 & 0.44 & 0.06 & -0.71 & -0.02 & 1.04 \\
\hline & W & -0.00608 & 0.04186 & 0.01427 & 0.03725 & 0.02601 & -0.01406 & -0.01885 & -0.48629 & -0.3593 & -0.18744 & -0.11209 & -0.06956 & -0.02951 \\
\hline & & -1.76 & 0.85 & 0.29 & 0.77 & 0.55 & -0.39 & -0.54 & -23.52 & -16.21 & -8.44 & -5.41 & -3.8 & -2.35 \\
\hline \multirow[t]{4}{*}{ NCP } & $\mathrm{O}$ & 0.03193 & 0.02294 & -0.02433 & 0.0095 & 0.00092 & 0.00261 & 0.01544 & 0.0297 & 0.03963 & -0.02521 & 0.03309 & 0.03433 & 0.05013 \\
\hline & & 6.45 & 1.12 & -1.21 & 0.49 & 0.05 & 0.14 & 0.85 & 1.23 & 1.68 & -1.13 & 2.04 & 2.47 & 4.02 \\
\hline & W & -0.01143 & 0.04877 & 0.01749 & -0.01017 & 0.01335 & 0.0227 & 0.01943 & -0.2783 & -0.07262 & -0.04518 & -0.02847 & -0.0031 & -0.00925 \\
\hline & & -2.74 & 2.83 & 1.04 & -0.63 & 0.85 & 1.47 & 1.26 & -13.69 & -3.66 & -2.4 & -2.09 & -0.26 & -0.88 \\
\hline \multirow[t]{4}{*}{ OSH } & $\mathrm{O}$ & 0.0443 & -0.15335 & -0.11703 & -0.01092 & -0.04086 & 0.03118 & 0.04464 & 0.1204 & 0.12199 & 0.0247 & 0.06719 & -0.10678 & -0.08532 \\
\hline & & 5.16 & -5.94 & -4.47 & -0.41 & -1.5 & 1.23 & 1.8 & 2.71 & 2.7 & 0.59 & 1.64 & -2.78 & -2.36 \\
\hline & W & 0.000659 & 0.1029 & 0.03249 & 0.0339 & 0.03147 & 0.02877 & -0.00567 & -0.11529 & -0.07228 & -0.06122 & -0.05589 & -0.03604 & -0.00399 \\
\hline & & 0.13 & 6.88 & 2.14 & 2.18 & 2 & 1.95 & -0.39 & -4.48 & -2.76 & -2.51 & -2.36 & -1.62 & -0.19 \\
\hline
\end{tabular}


Table 7

\section{Error Correction Model Results (cont'd)}

\begin{tabular}{|c|c|c|c|c|c|c|c|c|c|c|c|c|c|c|}
\hline \multicolumn{3}{|c|}{ Dep } & \multicolumn{6}{|c|}{ Option Lags } & \multicolumn{6}{|c|}{ Warrant Lags } \\
\hline Firm & Var & Alpha & $-5 \min$ & $-10 \min$ & $-15 \min$ & $-20 \mathrm{~min}$ & $-25 \min$ & $-30 \mathrm{~min}$ & $-5 \min$ & $-10 \min$ & $-15 \min$ & $-20 \min$ & $-25 \min$ & $-30 \min$ \\
\hline \multirow[t]{4}{*}{ PAS } & $\mathrm{O}$ & 0.03408 & -0.14976 & -0.05807 & -0.03197 & -0.03481 & -0.02815 & -0.000242 & 0.11025 & 0.00549 & 0.07287 & 0.03649 & 0.02021 & 0.00626 \\
\hline & & 5.33 & -7.65 & -3 & -1.72 & -1.94 & -1.66 & -0.01 & 3.76 & 0.19 & 2.61 & 1.46 & 0.89 & 0.29 \\
\hline & $\mathrm{W}$ & -0.00854 & 0.1027 & 0.06551 & 0.05912 & 0.01361 & -0.00232 & 0.03413 & -0.13959 & -0.0358 & -0.02587 & 0.02232 & -0.03267 & -0.01569 \\
\hline & & -1.97 & 7.76 & 5.01 & 4.72 & 1.12 & -0.2 & 3.11 & -7.05 & -1.81 & -1.37 & 1.32 & -2.12 & -1.06 \\
\hline \multirow[t]{4}{*}{ PDP } & $\mathrm{O}$ & 0.0044 & -0.26144 & -0.20573 & -0.13107 & -0.1285 & -0.05231 & -0.02744 & 0.00521 & 0.01398 & 0.02871 & 0.04804 & 0.04841 & 0.11355 \\
\hline & & 0.59 & -10.25 & -7.74 & -4.99 & -5.21 & -2.22 & -1.23 & 0.06 & 0.16 & 0.34 & 0.58 & 0.62 & 1.53 \\
\hline & W & -0.000463 & 0.00845 & 0.04361 & 0.02316 & 0.0063 & 0.01344 & -0.01687 & -0.14826 & -0.09569 & -0.03963 & 0.01423 & -0.02356 & -0.02556 \\
\hline & & -0.21 & 1.11 & 5.47 & 2.94 & 0.85 & 1.9 & -2.53 & -5.63 & -3.54 & -1.57 & 0.57 & -1.01 & -1.15 \\
\hline \multirow[t]{4}{*}{ SGB } & $\mathrm{O}$ & 0.04324 & -0.22217 & -0.08866 & -0.02992 & -0.05479 & -0.02358 & -0.00708 & 0.21278 & 0.11771 & 0.08723 & 0.02807 & 0.04033 & 0.03765 \\
\hline & & 3.76 & -12.27 & -5.05 & -1.81 & -3.55 & -1.58 & -0.5 & 5.66 & 3.18 & 2.65 & 1 & 1.56 & 1.54 \\
\hline & W & -0.03065 & 0.03382 & 0.04514 & 0.04033 & -0.00821 & 0.01361 & 0.0019 & -0.04936 & -0.19207 & -0.02807 & -0.06679 & -0.02087 & -0.03303 \\
\hline & & -5.22 & 3.66 & 5.04 & 4.78 & -1.04 & 1.79 & 0.26 & -2.57 & -10.18 & -1.67 & -4.65 & -1.59 & -2.65 \\
\hline \multirow[t]{4}{*}{ STO } & $\mathrm{O}$ & 0.07225 & -0.25688 & -0.11613 & -0.07037 & -0.01459 & -0.07166 & -0.02362 & 0.15863 & 0.18954 & 0.10855 & 0.04622 & 0.04557 & 0.00189 \\
\hline & & 5.66 & -11.94 & -5.19 & -3.22 & -0.74 & -3.77 & -1.32 & 3.97 & 4.74 & 2.79 & 1.39 & 1.68 & 0.08 \\
\hline & W & -0.00796 & 0.08271 & 0.06033 & 0.02527 & 0.01513 & -0.00602 & 0.02121 & -0.10351 & -0.05215 & -0.04568 & -0.01399 & 0.01259 & 0.00516 \\
\hline & & -1.19 & 7.32 & 5.13 & 2.2 & 1.45 & -0.6 & 2.26 & -4.94 & -2.48 & -2.23 & -0.8 & 0.89 & 0.4 \\
\hline \multirow[t]{4}{*}{ TLS } & $\mathrm{O}$ & -0.000356 & -0.14598 & -0.02031 & -0.06367 & -0.02191 & -0.04582 & -0.00571 & 0.0056 & -0.00114 & -0.00063 & 0.01397 & 0.05117 & -0.05206 \\
\hline & & -0.09 & -7.3 & -1 & -3.19 & -1.26 & -2.67 & -0.34 & 0.15 & -0.03 & -0.02 & 0.39 & 1.47 & -1.51 \\
\hline & W & -0.00541 & -0.00442 & 0.05921 & 0.03887 & -0.00512 & 0.00503 & 0.01513 & -0.05633 & -0.03168 & -0.04523 & -0.02449 & -0.02062 & -0.00649 \\
\hline & & -2.79 & -0.44 & 5.76 & 3.84 & -0.58 & 0.58 & 1.78 & -2.94 & -1.68 & -2.43 & -1.34 & -1.17 & -0.37 \\
\hline \multirow[t]{4}{*}{ WBC } & $\mathrm{O}$ & -0.01105 & -0.13571 & -0.01746 & -0.03132 & -0.05288 & -0.03305 & -0.12996 & 0.02544 & -0.00512 & -0.01025 & 0.00817 & 0.043 & 0.06847 \\
\hline & & -0.75 & -3.53 & -0.46 & -0.84 & -1.48 & -0.95 & -3.94 & 0.33 & -0.07 & -0.13 & 0.11 & 0.61 & 1.11 \\
\hline & W & -0.01843 & 0.01134 & 0.01621 & 0.03315 & 0.03855 & 0.00448 & -0.0137 & 0.06272 & 0.06067 & 0.01273 & -0.0258 & 0.01097 & 0.02161 \\
\hline & & -2.55 & 0.6 & 0.87 & 1.81 & 2.21 & 0.26 & -0.85 & 1.65 & 1.58 & 0.33 & -0.69 & 0.32 & 0.72 \\
\hline
\end{tabular}


Table 7

\section{Error Correction Model Results (cont’d)}

\begin{tabular}{|c|c|c|c|c|c|c|c|c|c|c|c|c|c|c|}
\hline \multicolumn{3}{|c|}{ Dep } & \multicolumn{6}{|c|}{ Option Lags } & \multicolumn{6}{|c|}{ Warrant Lags } \\
\hline Firm & Var & Alpha & $-5 \min$ & $-10 \min$ & $-15 \min$ & $-20 \mathrm{~min}$ & $-25 \min$ & $-30 \mathrm{~min}$ & $-5 \min$ & $-10 \min$ & $-15 \min$ & $-20 \min$ & $-25 \min$ & $-30 \min$ \\
\hline \multirow[t]{4}{*}{ WMC } & $\mathrm{O}$ & 0.01014 & -0.02986 & -0.01079 & -0.01394 & -0.0024 & 0.00485 & -0.0227 & 0.00423 & -0.00039 & -0.02052 & 0.00127 & -0.0058 & -0.00982 \\
\hline & & 2.67 & -1.48 & -0.56 & -0.71 & -0.13 & 0.32 & -1.52 & 0.51 & -0.04 & -1.82 & 0.11 & -0.46 & -0.77 \\
\hline & W & -0.0327 & 0.0575 & -0.02169 & -0.04365 & 0.03864 & 0.09817 & 0.02021 & -0.32004 & -0.15373 & -0.50358 & -0.17629 & -0.1219 & -0.13302 \\
\hline & & -2.42 & 0.8 & -0.32 & -0.62 & 0.6 & 1.81 & 0.38 & -10.73 & -4.35 & -12.53 & -4.22 & -2.71 & -2.93 \\
\hline \multirow[t]{4}{*}{ WOW } & $\mathrm{O}$ & 0.01966 & -0.11454 & -0.01607 & -0.03332 & -0.02664 & 0.01158 & -0.00409 & -0.0076 & 0.0712 & 0.06464 & 0.01449 & 0.0057 & 0.09166 \\
\hline & & 3.81 & -5.53 & -0.83 & -2.09 & -1.72 & 0.75 & -0.27 & -0.18 & 1.68 & 1.61 & 0.39 & 0.18 & 3.26 \\
\hline & W & -0.00325 & 0.01205 & 0.01979 & -0.00296 & 0.01027 & -0.00128 & -0.00322 & -0.08446 & -0.04639 & -0.00109 & 8E-05 & $-8.2 \mathrm{E}-05$ & 0.02803 \\
\hline & & -1.31 & 1.22 & 2.15 & -0.39 & 1.39 & -0.17 & -0.44 & -4.15 & -2.28 & -0.06 & 0 & -0.01 & 2.08 \\
\hline \multirow[t]{4}{*}{ WPL } & $\mathrm{O}$ & 0.01 & -0.07584 & -0.00804 & 0.01215 & 0.00134 & 0.00575 & 0.00416 & 0.04033 & -0.00893 & -0.03433 & -0.01146 & -0.01262 & -0.00485 \\
\hline & & 2.96 & -3.11 & -0.33 & 0.56 & 0.06 & 0.28 & 0.24 & 1.83 & -0.42 & -1.75 & -0.61 & -0.68 & -0.27 \\
\hline & W & -0.00587 & 0.03811 & 0.02541 & 0.0396 & -0.00873 & 0.00798 & -0.01649 & -0.19161 & -0.0567 & -0.00736 & 0.0265 & 0.00663 & -0.01237 \\
\hline & & -1.62 & 1.45 & 0.98 & 1.7 & -0.39 & 0.36 & -0.87 & -8.1 & -2.5 & -0.35 & 1.31 & 0.33 & -0.64 \\
\hline
\end{tabular}

